\title{
STUDIES ON MEIOTIC CHROMOSOMES AND SPERMATOZOAN HEADS IN MICE TREATED WITH LSD
}

\author{
N. E. SKAKKEBæK AND R. A. BEATTY \\ Cytogenetic Laboratory, Department of Obstetrics $A$ and Gynaecology I, \\ Rigshospitalet, University of Copenhagen, and A.R.C. Unit of Animal Genetics, \\ Institute of Animal Genetics, West Mains Road, Edinburgh 9
}

(Received 15th Fuly 1969)

Since Cohen, Marinello \& Back (1967) first reported an effect of LSD on human chromosomes, several workers have shown an increased frequency of chromosomal abnormalities in leucocytes in patients who have been treated with the drug or who have illegally taken it (Gohen, Hirschhorn \& Frosch, 1967; Irwin \& Egozcue, 1967; Nielsen, Friedrich, Jacobsen \& Tsuboi, 1968; Hungerford, Taylor, Shagass, La Badie, Balaban \& Paton, 1968). Other workers were unable to demonstrate any effect of the drug on the chromosomes in human leucocytes (Loughman, Sargent \& Israelstam, 1967; Bender \& Siva-Sankar, 1968; Sparkes, Melnyk \& Bozzetti, 1968). Experimental investigations have given preliminary evidence of an effect of LSD on meiotic chromosomes in mice (Skakkebæk, Philip \& Rafaelsen, 1968; Cohen \& Mukherjee, 1968). In another study of meiotic chromosomes in LSD-treated mice, the results were essentially negative (Jagiello \& Polani, 1969). The present report supports the former findings and also gives evidence of an effect on the morphology of the spermatozoan head in mice.

Four 6- to 8-week-old mice of the Leo strain were injected subcutaneously with LSD $1 \mathrm{mg} / \mathrm{kg}$ body weight each Tuesday and Friday for 5 weeks. A control run in parallel consisted of four mice of the same strain and age injected with saline only. Two days after the last injection the mice were coded and hemicastrated. Meiotic preparations from the eight testes were made during one day by a slight modification of the air drying technique of Evans, Breckon \& Ford (1964). These preparations were used for study of the chromosomal as well as the spermatozoan morphology.

Two hundred cells in diakinesis/metaphase I and 100 cells in metaphase II were scored in each mouse, except that only 145 cells in diakinesis/metaphase I were suitable for analysis in case no. 26. Of those in diakinesis/metaphase I, only cells in which the bivalents were well spread were used. Metaphase II was studied only in cells with a heterochromatic X chromosome because our experience is that with the present technique this chromosome is the only one which has such a clear morphology that analysis of chromosome breakage is possible. An abnormality was scored as a break only if the axis of the two parts of the chromosome was broken. Gaps were defined as regions of discontinuity 
without displacement of the axis. Regions of pale-staining material were registered as secondary constrictions. Due to the high degree of spiralizing, however, no attempt was made to score secondary constrictions in metaphase II. A distinction between gap and break at this stage was made, but was often difficult. Therefore, the total number of the two types of abnormalities may give a truer picture of possible chromosome damage at this stage. Analysis was carried out blindly and decoding was not performed until the investigation was finished. There was a high frequency of abnormalities in two of the LSD-treated mice,

TABLE 1

ABNORMALITIES FOUND IN CELLS IN DIAKINESIS/METAPHASE I

\begin{tabular}{|c|c|c|c|c|c|c|}
\hline \multirow{2}{*}{$\begin{array}{l}\text { Case } \\
\text { no. }\end{array}$} & \multirow{2}{*}{$\begin{array}{l}\text { No. of } \\
\text { cells analysed }\end{array}$} & \multicolumn{3}{|c|}{$X$ chromosomal } & \multirow{2}{*}{$\begin{array}{c}\text { Autosomal } \\
\text { abnormalities }\end{array}$} & \multirow[b]{2}{*}{ Tota } \\
\hline & & Breaks & Gaps & Sec. const.* & & \\
\hline $\begin{array}{l}\text { LSD treated } \\
23 \\
24 \\
26 \\
27\end{array}$ & $\begin{array}{l}200 \\
200 \\
145 \\
200\end{array}$ & $\begin{array}{l}1 \\
0 \\
0 \\
0\end{array}$ & $\begin{array}{l}4 \\
0 \\
1 \\
0\end{array}$ & $\begin{array}{r}18 \\
2 \\
7 \\
3\end{array}$ & $\begin{array}{l}0 \\
0 \\
0 \\
0\end{array}$ & $\begin{array}{r}23 \\
2 \\
8 \\
3\end{array}$ \\
\hline $\begin{array}{c}\text { Control } \\
21 \\
22 \\
25 \\
28\end{array}$ & $\begin{array}{l}200 \\
200 \\
200 \\
200\end{array}$ & $\begin{array}{l}0 \\
0 \\
0 \\
0\end{array}$ & $\begin{array}{l}0 \\
0 \\
0 \\
0\end{array}$ & $\begin{array}{l}3 \\
6 \\
4 \\
2\end{array}$ & $\begin{array}{l}0 \\
0 \\
0 \\
0\end{array}$ & $\begin{array}{l}3 \\
6 \\
4 \\
2\end{array}$ \\
\hline
\end{tabular}

Sec. const. $=$ Secondary construction.

TABLE 2

ABNORMALITIES FOUND IN CELLS IN METAPHASE II WITH A HETEROCHROMATIC $\mathrm{X}$ CHROMOSOME

\begin{tabular}{l|c|rr|r}
\hline \multicolumn{1}{c|}{$\begin{array}{c}\text { Case } \\
\text { no. }\end{array}$} & $\begin{array}{c}\text { No. of } \\
\text { cells analysed }\end{array}$ & \multicolumn{2}{|c|}{ X chromosomal } & \multirow{2}{*}{ Total } \\
\cline { 3 - 4 } LSD treated & & Gaps & \\
23 & 100 & 2 & 5 & 7 \\
24 & 100 & 0 & 2 & 2 \\
26 & 100 & 10 & 35 & 45 \\
27 & 100 & 0 & 3 & 3 \\
Control & 100 & 0 & 4 & 4 \\
21 & 100 & 1 & 7 & 8 \\
22 & 100 & 2 & 13 & 15 \\
25 & 100 & 0 & 4 & 4 \\
28 & & & \\
\hline
\end{tabular}

an observation which we make as a datum contributed to the general literature but not as formal evidence of an effect of LSD. Table 1 shows that in case no. 23 relatively many abnormalities in diakinesis/metaphase I were found. Case no. 26 showed a higher number of abnormalities in metaphase II than the remaining LSD-treated or the control mice (Table 2). All the detected changes in diakinesis/metaphase I were located on the $\mathrm{X}$ chromosome. This may, however, be due to the fact that a change in structure with the present technique would be easier to identify in the $\mathrm{X}$ chromosome, which in diakinesis/metaphase $\mathrm{I}$ is more easily scrutinized than are the autosomes. 
Of the LSD-treated mice, all of which were given the same dose of LSD, only two showed an obvious increased frequency of structural changes in the chromosomes compared with the controls. A previous experiment also showed a large variation in the number of structural changes and no correlation between the size of dose and the number of abnormalities was found (Skakkebæk et al., 1968).

For study of spermatozoan morphology, two slides were taken at random from each mouse. Besides cells in metaphase, preparations contained all types of germinal elements including immature and mature spermatozoan heads. The sixteen slides were coded in a randomized order and given to a technician, $\mathrm{Mr} \mathrm{V}$. Coulter, who was asked to classify them into two groups of eight (A and B) according to whatever criteria he could devise. After decoding, it was found that seven out of eight slides in Group A came from LSD-treated mice and seven out of eight slides in Group B from control mice. The chance of obtaining an association as good as or better than this merely by chance is close to 1 in 100 , assuming that the only operative sources of variation are the true difference between experimental and control groups and random observational uncertainty per slide. A real visual difference between the spermatozoan heads of LSD-treated and control mice seems, therefore, to exist.

The following criteria were elaborated during the visual classification of the slides: (1) the degree of roundedness of the main convex side of the head: (2) a narrow versus a wide head: (3) an obtuse rather than a right-angle between the main axis of the midpiece and the somewhat flattened posterior edge of the head: (4) a long rather than a short acrosomal 'hook' at the anterior tip of the head. Discriminant function analysis that was rather approximate because of the nature of the data suggested that criteria 3 and 4 were of little value. The main discrimination came from criteria 1 and 2, which indicated that spermatozoa of LSD-treated mice had a more rounded convex side of the head and also had broader heads in comparison with controls. It cannot be stated at present whether these are effects on spermiogenesis rather than on the testis or the body as a whole.

We are grateful to Dr W. G. Hill for the calculation of probability and to Mr R. Middleton of the Edinburgh Regional Computing Centre for multiple regression computations. The work was supported by The Danish National Service for the Mentally Retarded and by a Grant from the Ford Foundation.

\section{REFERENCES}

Bender, L. \& Siva-Sankar, D. V. (1968) Chromosome damage not found in leukocytes of children treated with LSD-25. Science, N.Y.159, 749.

Cohen, M. M., Hirschhorn, K. \& Frosch, W. A. (1967) In vivo and in vitro chromosomal damage induced by LSD-25. New Engl. 7. Med. 227, 1043.

Cohen, M. M., Marinello, M. J. \& Back, N. (1967) Chromosomal damage in human leukocytes induced by lysergic acid diethylamide. Science, $\mathcal{N} . \Upsilon .155,1417$.

Cohen, M. M. \& MukherJeE, A. B. (1968) Meiotic chromosome damage induced by LSD-25. Nature, Lond. 219, 1072.

Evans, E. P., Breckon, G. \& Ford, G. E. (1964) An air-drying method for meiotic preparations from mammalian testis. Cytogenetics, 3, 289. 
Hungerford, D. A., Taylor, K. M., Shagass, G., La Badie, G. U., Balaban, G. B. \& Paton, G. R. (1968) Cytogenetic effects of LSD-25 therapy in man. F. Am. med. Ass. 206, 2287.

IRWIN, S. \& Egozcue, J. (1967) Chromosomal abnormalities in leukocytes from LSD-25 users. Science, N.Y. 157, 313.

Jagiello, G. \& Polani, P. E. (1969) Mouse germ cells and LSD-25. Cytogenetics, 8, 136.

Loughman, W. D., Sargent, T. W. \& Israelstam, D. M. (1967) Leukocytes of humans exposed to lysergic acid diethylamide: lack of chromosomal damage. Science, $\mathcal{N} . Y, 158,508$.

Nielsen, J., Friedrich, U., Jacobsen, E. \& Tsubor, T. (1968) Lysergide and chromosome abnormalities. Br. med. F. ii, 801 .

Skakkebek, N. E., Philip, J. \& Rafaelsen, O. J. (1968) LSD in mice: abnormalities in meiotic chromosomes. Science, N.Y. 160, 1246.

Sparkes, R. S., Melnyk, J. \& Bozzetti, L. P. (1968) Chromosomal effect in vivo of exposure to lysergic acid diethylamide. Science, $\mathcal{N}$. r. 160, 1343. 